\title{
UM COELHINHO NA GARGANTA: O ABSURDO COMO RECORTE DO INSÓLITO FICCIONAL
}

\author{
A bunny in the throat: the absurd genre as a clipping of the fictional \\ strangeness
}

\section{Bruno Macêdo Mendonça* \\ Universidade de Coimbra}

\begin{abstract}
Resumo: A hipótese do artigo, e consequentemente da tese de Doutorado do autor, é a de que há um conjunto crescente de narrativas, modernas e contemporâneas, que não podem ser analisadas segundo quaisquer dos parâmetros conceituais atribuídos aos subgêneros do insólito ficcional (Maravilhoso, Realismo Mágico ou Fantástico). Ainda que a literatura especializada tente recorrentemente enquadrá-las de acordo com o Fantástico, nem a construção original de Tzvetan Todorov, nem as reformulações posteriores, desenvolvidas por outros teóricos, são convincentes em suas tentativas neste sentido. O presente trabalho, portanto, objetiva problematizar a questão apresentando um corpus de cinco textos representativos deste subgênero ao qual demos provisoriamente o nome de Absurdo, seguindo o insight do próprio Todorov em sua obra clássica. Com a finalidade de apontar as peculiaridades desta categoria, faz-se um breve estudo sobre os demais subgêneros do insólito, delineando suas características a partir da teoria literária para, ao final, numa perspectiva comparada, realizar algumas observações sobre as particularidades que desde já, ainda de modo incipiente, podem ser notadas no subgênero proposto. Trata-se de um artigo exploratório, visando à especificação da problemática que será objeto dos estudos do autor no Doutoramento em Línguas Modernas: Culturas, Literaturas e Tradução, da Universidade de Coimbra, cujo início ocorreu em setembro de 2017.
\end{abstract}

Palavras-chave: Literatura Fantástica. Insólito. Gênero Absurdo.

Abstract: The hypothesis addressed in the article, and consequently in the author's $\mathrm{PhD}$ dissertation, is that there is an increasing number of narratives, modern and contemporary ones, which cannot be analysed according to any of the conceptual parameters associated with the fictional strangeness subgenres (Marvelous, Magical Realism or Fantastic). Although the specialized literature attempts recurrently to fit them in the Fantastic, neither the original construction of Tzvetan Todorov, nor the further redrawings developed by other theorists are convincing enough when attempting to do so. Therefore, the current work aims to discuss this

Esta obra está licenciada sob uma Creative Commons - Atribuição 4.0

\footnotetext{
* Doutorando em Línguas Modernas na Universidade de Coimbra, Portugal. Possui graduação em Direito pela Universidade Federal de Pernambuco (2003). É Especialista em Relações Internacionais pela Universidade de Brasília (2008) e Mestre em Relações Internacionais (2012) pela mesma Universidade. E-mail: bmacedomendonca@hotmail.com.
}

iD https://orcid.org/0000-0002-6850-7268 
question, presenting a corpus of five texts representative of this genre, which we named temporarily of Absurd thus following the insight of Todorov's classical work. With the purpose of pointing out the singularities of this category, a brief study about the other subgenres of the Strange is conducted and from the literary theory its characteristics are outlined in order to, in the end, in a comparative perspective, make some observations about the features, that from now on, rather incipiently, can already be noticed in the proposed subgenre. This is an exploratory article that aims to specify the problematic, which will be the object of the author's studies in the field of the $\mathrm{PhD}$ in Modern Languages: Cultures, Literatures and Translation in the University of Coimbra that began in September 2017.

Keywords: Fantastic Literature. Strange. Absurd Genre.

Recebido em: 16/02/2018

Aceito em: 28/05/2018

Quase todos os contos que escrevi pertencem ao gênero chamado fantástico por falta de melhor nome.

Julio Cortázar

Estou farto deste populismo-fantástico-humorístico-coiso.

Narrador de Mario de Carvalho

Intraitable, décidément: telle est bien la qualité première - et dernière de l'insolite. N'en va-t-il pas, au demeurant, de son essence même de ne pas se laisser mettre em cage? Bien fou que croirait avoir attrapé le diable par la queue!

Myriam Boucharenc

\section{Introdução}

O universo dos conceitos é traiçoeiro. Quando se imagina que uma definição deu cabo dos fenômenos que pretende explicar, uma dúvida, um aspecto específico, um detalhe surge inesperadamente para pôr em xeque toda a lapidada construção conceitual. Os fenômenos, e aqui trato do fenômeno literário, têm essa habilidade de não se deixar aprisionar pelas palavras - o que os tornam ainda mais fascinantes.

A pretensão de formular conceitos perfeitos, que deem conta da totalidade de seu objeto, portanto, é, nada mais, nada menos do que uma quimera. Lembro-me a propósito de um conto de Julio Cortázar, Sua fé nas ciências (CORTÁZAR, 2017, p. 126-121), que parece ilustrar, de modo divertido, esta constatação:

Uma esperança ${ }^{1}$ acreditava nos tipos fisionômicos, tais como os de nariz achatado, os de cara de peixe, os de cara grande e inchada, os amarelados e os sobrancelhudos, os de cara intelectual, os de estilo cabeleireiro etc. Disposta a classificar definitivamente esses grupos, começou a fazer grandes listas de conhecidos e os dividiu nos grupos acima mencionados. Tomou então o primeiro grupo, integrado por oito rapazes de nariz achatado e percebeu com surpresa que na realidade eles se subdividiam em três grupos, isto é: os de

\footnotetext{
${ }^{1}$ A Esperança é um ser ficcional criado por Cortázar. Outros seres, cada qual com características próprias, são os Cronópios e os Famas. Encontram-se todos na obra Histórias de cronópios e de famas (CORTÁZAR, 2017).
}

Anu. Lit., Florianópolis, v. 23, n. 2, p. 80-99, 2018. ISSNe 2175-7917 
nariz achatado bigodudos, os de tipo boxeador, os estilo contínuo de ministério, compostos respectivamente por três, três e dois narizes achatados. Apenas os separou em seus novos grupos (no Café Paulista da rua San Martin, onde os reunira com grande trabalho e não pouco mazagrán bem gelado) percebeu que o primeiro subgrupo não era igual, porque os dois bigodudos de nariz achatado pertenciam ao tipo capivara, enquanto o restante era com toda certeza um nariz achatado de corte japonês. Afastando-o com a ajuda de um bom sanduíche de enchova e ovo cozido, organizou o subgrupo dos dois capivaras, e se dispunha a inscrevê-lo em seu caderno de trabalhos científicos quando um dos capivaras olhou para um lado e o outro capivara olhou para o lado oposto, em consequência do que a esperança e os demais candidatos puderam perceber que, enquanto o primeiro capivara era evidentemente um nariz achatado braquicéfalo, o outro possuía um crânio muito mais apropriado para pendurar um chapéu do que para encaixá-lo. Assim foi que se dissolveu o subgrupo, e do resto nem é bom falar porque os demais sujeitos haviam passado do mazagrán à cachaça queimada, e a essa altura dos acontecimentos a única semelhança entre eles era o firme propósito de continuarem bebendo à custa da esperança.

O terreno das classificações é tão minado que tudo o que se pode fazer, como diria o autor argentino, são aproximações (CORTÁZAR, 2015, p. 25) do fenômeno literário em questão. A discussão sobre os gêneros enquadra-se nesta problemática de aproximação do objeto, sendo prudente evitar empreitadas de apreensão absoluta do seu significado.

Não quero propor um debate nominalista, isto é: não se busca aqui o melhor nome ou conceito para o mesmo fenômeno, e sim conceitos delineadores de fenômenos distintos. Se se dá às narrativas onde aparecem fantasmas o nome de fantasmagóricas ou de terror, isto não passa de uma discussão estéril, sem interesse algum para a teoria. Mas se o que o conceito distingue são narrativas cujo matiz é peculiar, diferenciado, a tarefa pode ter algum interesse, desde que o fenômeno que se quer delimitar represente algo além dele mesmo - uma época, costumes, visões de mundo. Os modos de ser da Literatura não se dão no vácuo, como é evidente.

Porque os conceitos são aproximações, sempre se busca aperfeiçoá-los, e alguns parecem chegar mais perto de seus objetos do que outros. O Realismo em Literatura, por exemplo, não é objeto de grande controvérsia na teoria, a menos que se adentre - e há quem o faça, num âmbito de estudos que não é o nosso - a discussão filosófica acerca da consistência do próprio conceito de realidade.

O gênero Maravilhoso - e em menor grau o chamado Realismo Mágico ou Realismo Maravilhoso, que é objeto de extensa discussão, mas não de tanta controvérsia, ao que me parece - também não sofre ataques violentos às suas bases conceituais. O mesmo não ocorre com os conceitos de Fantástico ou, num nível claramente problemático, o de Insólito. Nestes casos, a confusão é extrema, como se demonstrará.

Quando iniciei a pesquisa que me trouxe aos bancos da Universidade de Coimbra, interessava-me - como ainda me interesso - por um fenômeno literário cujos traços me pareciam de algum interesse reflexivo. Como tais traços eram de natureza, no mínimo, insólita (e aqui uso o termo em seu sentido comum), voltei-me para estes estudos de gênero encontrados 
na literatura. E qual não foi minha surpresa perceber que, embora as narrativas que me interessavam certamente se encontrassem em algum lugar perdido em meio às temáticas do insólito, era simplesmente impossível, a partir de minhas leituras, afirmar a qual gênero, subgênero, categoria ou corrente pertenciam. Ainda mais desafiador: qual seria sua razão de ser? Por que subsistia como fenômeno e o que poderia, eventualmente, representar?

Um dos objetivos deste artigo é o de problematizar a discussão acima, numa espécie de introdução ao tema de minha tese de Doutoramento em Línguas Modernas na Universidade de Coimbra, que pretendo desenvolver ao longo dos próximos quatro anos. Outras finalidades mais ambiciosas - que serão apenas mencionadas neste texto, mas buscadas ao longo do curso - são: 1) a tentativa de desatar o nó conceitual atinente às categorias do fantástico e do insólito; 2) a identificação do fenômeno que nos interessa e sua análise a partir de um corpus de narrativas que o representam; 3) a discussão - um tanto filosófica, é verdade - acerca das possíveis razões de sua existência.

$\mathrm{O}$ artigo divide-se em cinco partes. Na primeira faço remissão a cinco narrativas cujas peculiaridades me chamam a atenção pela sua natureza insólita; na segunda apresento os gêneros ou categorias nas quais poderiam ser eventualmente enquadradas; na terceira teço considerações sobre o termo insólito, tal como vem sendo discutido na teoria; na quarta apresento propostas ainda incipientes acerca do enquadramento do insólito num esquema mais compreensível de classificação; na quinta, por fim, desenvolvo reflexões prévias sobre o que poderia ser considerado como um subgênero do insólito, ao qual Todorov deu o título de absurdo, mas que também pode ser encarado como o insólito no seu sentido mais estrito.

\section{Cinco contos, uma provocação}

Como proposto, faço o relato parcial e resumido de cinco narrativas curtas:

1) O solteirão "já meio idoso" Blumfeld vive uma vida solitária que se lhe afigura bastante penosa, tanto que cogita, vez ou outra, adquirir um cachorro. Certo dia, ao subir as escadas do seu apartamento, escuta um barulho singular atrás da porta. Ao abri-la, depara-se com "duas pequenas bolas de celuloide, brancas, com estrias azuis", saltando sobre o assoalho, "uma ao lado da outra e de cá para lá. Quando uma bate no solo, a outra está no alto e assim, incansáveis, executam o seu jogo".

2) Num beco peculiar da cidade de Lisboa, à noite, Andrade da Mula sai à janela de sua residência e boceja um desses bocejos "do tamanho de uma casa". Então algo acontece com a Lua. Ela "deslocou-se um bocadinho, assim como quem se desequilibrou, entrou a descer devagar, ressaltou numa ponta de nuvem que por ali pairava feito parva, e foi enfiar-se inteirinha na boca do Andrade, que só fez 'gulp' e esbugalhou os olhos muito".

3) Um sujeito se detém diante do mar, "absorvido com ridículas lembranças". Alguém o interpela, pedindo-lhe um cigarro. O sujeito responde de modo ríspido, sem se voltar para seu interlocutor, ameaçando chamar a polícia. O pedinte roga-lhe que "não se zangue", mas que saia da sua frente porque também aprecia observar o mar. Ao se retornar, exasperado pela impertinência, o indivíduo dá de cara com "um coelhinho cinzento", que o interpela 
delicadamente: "você não dá, é porque não tem, não é, moço?".

4) Num 25 de março, em Petersburgo, o barbeiro Ivan Yákovlievitch, ao cortar seu pão do café da manhã, encontra no miolo um nariz. No mesmo dia, o assessor de colegiado Kovaliov acorda e percebe que perdeu seu nariz. O lugar onde tinha o nariz "estava inteiramente plano". O assessor sai "voando direto para a casa do chefe de polícia". Mas no meio do caminho tem um encontro: vê um senhor saltando de uma carruagem. Para sua surpresa, reconhece "naquele senhor o seu próprio nariz!".

5) Um sujeito escreve uma carta à amiga Andrée, dizendo-lhe que não queria ter ido morar, por quatro meses, "no seu apartamento da rua Suipacha". Conta-lhe que se mudou na quinta-feira passada. Avisou à empregada que ia se instalar no apartamento e subiu no elevador. Mas eis que, diz o personagem, "exatamente entre o primeiro e o segundo andar senti que ia vomitar um coelhinho". Desculpa-se com a amiga por nunca ter the contado que vomita coelhinhos e descreve todo o processo: "quando sinto que vou vomitar um coelhinho, enfio dois dedos na boca como um alicate aberto e espero sentir na garganta a penugem morna que sobe como uma efervescência de sal de frutas. Tudo é veloz e higiênico, transcorre num instante brevíssimo. Tiro os dedos da boca e neles vem um coelhinho branco agarrado pelas orelhas"

Diante das narrativas acima, minha pergunta é: em que vertente do insólito - para me utilizar de uma expressão contida no título do livro organizado por Flávio García e Maria Cristina Batalha (GARCÍA; BATALHA, 2012) - se enquadram tais histórias? Para responder a esta indagação, necessário se faz delinear, ainda que superficialmente, os contornos dos gêneros por assim dizer antirrealistas mais discutidos na Literatura.

\section{Realismo versus Maravilhoso, Fantástico e Realismo Mágico}

Pode-se abordar o Realismo na Literatura seja de um ponto de vista estático, o que farei neste tópico, tendo em vista sua posição frente às demais categorias estudadas; seja de um ponto de vista dinâmico ou evolutivo, o que será objeto de breve menção nas considerações finais do trabalho, podendo-se analisá-lo a partir de seu surgimento na história literária. Esta última abordagem dá ensejo a que se pergunte pelas razões de sua aparição e, posteriormente, pelos motivos que o levaram a ser desafiado em seus pressupostos por outros gêneros.

É sempre bom lembrar, como faz Umberto Eco em seus Seis passeios pelos bosques da ficção, a existência de uma norma básica para se lidar com o texto ficcional:

[...] o leitor precisa aceitar tacitamente um acordo ficcional, que Coleridge chamou de 'suspensão da descrença'. O leitor tem de saber que o que está sendo narrado é uma história imaginária, mas nem por isso deve pensar que o escritor está contando mentiras. De acordo com John Searle, o autor simplesmente finge dizer a verdade. Aceitamos o acordo ficcional e fingimos que o que é narrado de fato aconteceu (ECO, 2017, p. 81, grifos do autor).

\footnotetext{
${ }^{2}$ Mais um coelho, a exemplo da narrativa três. $\mathrm{O}$ animal parece representar um fetiche em muitas histórias fantasiosas. Recorde-se, por oportuno, que em Alice no país das maravilhas, de Lewis Carroll, a personagem segue um coelho branco até sua toca e nela cai, adentrando assim o universo maravilhoso da obra.
}

Anu. Lit., Florianópolis, v. 23, n. 2, p. 80-99, 2018. ISSNe 2175-7917 
A Escola Realista - nesse sentido mais do que qualquer outra - pretende recriar, embora baseada no acordo ficcional, um universo onde impera a verossimilhança. Em outras palavras, o que ocorre numa ficção realista poderia, dentro do quadro das leis científicas conhecidas de determinada época, ocorrer dentro de nossa realidade - a do leitor, quero dizer.

Por esta razão, o Realismo cria cenários que "copiam" a realidade, reproduzindo locais, narrativas, ações e acontecimentos possíveis no mundo real. Luciana Morais da Silva, pesquisadora da temática insólita, assim traduz a questão: “os mundos possíveis ficcionais se constituem a partir de uma referência de base, gestados por meio de uma plena ancoragem no mundo real, mundo dos seres de carne e osso, semanticamente equacionados pelo imaginário do artista" (SILVA, 2016, p. 50). Mais adiante acrescenta que estes mundos ficcionais em que o insólito se manifesta teriam "o mesmo alicerce dos mundos de matriz real-naturalista" (SILVA, 2016, p. 55).

A tentativa de criar universos ficcionais factíveis, "reais", resultou na elaboração de obras muitas vezes extensas, com modelos de descrição totalizantes, onde o autor deixava menos espaço livre para a imaginação do leitor. Pense-se em romances como os de Honoré de Balzac, Victor Hugo ou Fiódor Dostoievski, nos quais a geografia de um quarto, por exemplo, era objeto de longas descrições, com o apontamento do que o cômodo continha, da disposição dos seus móveis, etc ${ }^{3}$. Todos estes recursos visavam à referida verossimilhança, que supostamente aproximava a ficção do real, dando-lhe (à criação) ares de "quase verdade" ou de pas de fiction du tout.

O gênero Maravilhoso, ao contrário, parte do pressuposto de que a narrativa será - e o leitor o sabe - fantasiosa ${ }^{4}$. Trata-se de um segundo grau de ilusão, se assim posso me expressar. Sabe-se que o narrado é uma ficção (1); sabe-se que esta ficção é inverossímil (2) ${ }^{5}$. No gênero maravilhoso, que cronologicamente precede o Realismo, os acontecimentos sobrenaturais "não provocam qualquer surpresa: nem o sono de cem anos, nem o lobo que fala, nem os dons mágicos das fadas" (TODOROV, 2010, p. 60).

\footnotetext{
${ }^{3}$ A crítica de André Breton (um autor que reconhecidamente influenciou os primeiros escritores do Realismo Mágico, em particular Alejo Carpentier) a este sujeito é violenta: "Et les descriptions! Rien n'est comparable au néant de celles-ci; ce n'est que superposition d'images de catalogue, l'auteur en prend de plus en plus à son aise, il saisit l'occasion de me glisser ses cartes postales, il cherche à me faire tomber d'accord avec lui sur des lieux communs: 'La petite pièce dans laquelle le jeune homme fut introduit était tapissée de papier jaune: il y avait des géraniums et des rideaux de mousseline aux fenêtres; le soleil couchant jetait sur tout cela une lumière crue... La chambre ne renfermait rien de particulier. Les meubles, en bois jaune, étaient tous très vieux. Un divan avec un grand dossier renversé, une table de forme ovale vis-à-vis du divan, une toilette et une glace adossées au trumeau, des chaises le long des murs, deux ou trois gravures sans valeur qui représentaient des demoiselles allemandes avec des oiseaux dans les mains, - voilà à quoi se réduisait l'ameublement'. (Dostoïevski: Crime et châtiment). Que l'esprit se propose, même passagèrement, de tels motifs, je ne suis pas d'humeur à l'admettre. On soutiendra que ce dessin d'école vient à sa place, et qu'à cet endroit du livre l'auteur a ses raisons pour m'accabler. Il n'en perd pas moins son temps, car je n'entre pas dans sa chambre" (BRETON, 2005, p. 17-18).

${ }^{4}$ Isto não significa que não haja qualquer referência ao mundo real. O real é sempre o ponto de partida das narrativas ficcionais, por mais fantasiosas que sejam. Nas palavras de Umberto Eco, "os mundos ficcionais são parasitas do mundo real" (2017, p. 89).

${ }^{5}$ É sempre bom lembrar, na precisa lição de Tzvetan Todorov, que "a linguagem literária é uma linguagem convencional em que a prova da verdade é impossível: a verdade é uma relação entre as palavras e as coisas que estas designam. Ora, em literatura, estas "coisas" não existem. Ao contrário, a literatura conhece uma exigência de validade ou de coerência interna" (TODOROV, 2010, p. 91).
}

Anu. Lit., Florianópolis, v. 23, n. 2, p. 80-99, 2018. ISSNe 2175-7917 
Associa-se esta categoria aos contos de fadas, narrativas que ocorrem dentro do que J.R.R. Tolkien, num conhecido ensaio, chamou de Reino Encantado. Ensina Tolkien:

disse que o sentido de "histórias sobre fadas" era demasiado restrito. É restrito demais mesmo que rejeitemos o tamanho diminuto, pois no uso normal em língua inglesa os contos de fadas não são histórias sobre fadas ou elfos, mas histórias sobre o Reino Encantado, Faërie, o reino ou estado no qual as fadas existem (TOLKIEN, 2017, p. 09).

A expressão reino encantado pode ser um tanto enganadora porque a palavra "reino" direciona a imaginação para histórias com reis, princesas e todo seu imaginário correlato. É claro, no entanto, que Tolkien se referia a um "universo" encantado, tanto que cita expressamente Charles Perrault, autor de Cinderela, Chapeuzinho vermelho, A bela adormecida e o Gato de Botas (TOLKIEN, 2017, p. 12), além de afirmar que "a face essencial do Reino Encantado é a do meio, a Mágica" (TOLKIEN, 2017, p. 25). Neste universo encantado, parte das leis da natureza não vigoram e animais podem falar com humanos ou bonecos de madeira ganhar vida, como em Pinóquio, de Carlo Collodi.

Regina Michelli (GARCÍA, 2008, p. 37), citando Rosária Monteiro, relembra temas constantes do gênero, bem como traços destas narrativas:

Hobbits, espadas mágicas, mundos planos transportados por tartarugas, dinossauros falantes, tudo isto é 'impossível', contrário às noções consensuais da realidade. Porém, a estrutura narrativa, o rigor da descrição, a dimensão humana dos seres imaginários (que potencia a identificação do leitor com os heróis) e, desejavelmente, a qualidade poética aliada a uma capacidade imaginativa imensa, tudo isto contribui para tornar o fantástico verossímil ${ }^{6}$.

Há outros traços peculiares a este tipo de narrativa, como o apelo moral de seus enredos ou a ocorrência de finais felizes. Normalmente representam uma espécie de enunciação alegórica de valores sociais, com oposição clara entre o Bem e o Mal, e o estímulo à ação virtuosa, sempre compensada ao término do texto. Embora Tolkien discorde deste posicionamento, costuma-se dizer que são histórias para crianças, em razão de seu caráter inverossímil, que um adulto supostamente não "compraria", e pelos seus aspectos moralista e pedagógico.

Haveria ainda muito o que dizer sobre este gênero, mas não me sobra espaço. Lembro novamente que o Maravilhoso antecede o Realismo e seu apego à criação ficcional pautada pela imitação do mundo real. Seu momento (da vertente realista) glorioso - e com isto não quero dizer que desapareceu, muito pelo contrário - foi o século XIX, com a consolidação do romance. Uma das facetas deste, nos seus primórdios, era inserir suas personagens em ambientes que eram verdadeiros espelhos da sociedade em que viviam seus autores.

\footnotetext{
${ }^{6}$ Expressando uma ideia semelhante à da parte final do comentário, J.R.R Tolkien enfatiza: "O que acontece de fato é que o criador da história mostra ser um 'subcriador' de sucesso. Ele faz um Mundo Secundário no qual nossa mente pode entrar. Dentro dele, o que ele relata é 'verdade', concorda com as leis daquele mundo. Portanto acreditamos, enquanto estamos por assim dizer do lado de dentro. No momento em que surge a incredulidade, o encanto se rompe; a magia, ou melhor, a arte fracassou" (TOLKIEN, 2017, p. 36).
}

Anu. Lit., Florianópolis, v. 23, n. 2, p. 80-99, 2018. ISSNe 2175-7917 
Com o surgimento da literatura Fantástica, que segundo seu mais famoso teórico teve vida curta (TODOROV, 2010, p. 174-175), restrita ao período entre o fim do século XVIII e o século XIX, este espelho do real sofre uma rachadura. No gênero Fantástico, a verossimilhança encontra-se sob ataque: eventos insólitos ocorrem de maneira a pôr narrador e leitor em dúvida acerca da integridade do real. Um e outro são obrigados a se questionar se os acontecimentos narrados são naturais, isto é, se obedecem às leis da natureza conhecidas pelo homem; ou se, ao contrário, as transgridem, sendo, portanto, sobrenaturais.

O critério definidor do gênero, segundo Tzvetan Todorov, é justamente esta hesitação. Nesse sentido, ela é "experimentada por um ser que só conhece as leis naturais, face a um acontecimento aparentemente sobrenatural" (TODOROV, 2010, p. 31). Especificando as condições de existência do fantástico, o mesmo autor ensina:

Primeiro, é preciso que o texto obrigue o leitor a considerar o mundo das personagens como um mundo de criaturas vivas e a hesitar entre uma explicação natural e uma explicação sobrenatural dos acontecimentos evocados. A seguir, esta hesitação pode ser igualmente experimentada por uma personagem; desta forma o papel do leitor é, por assim dizer, confiado a uma personagem e ao mesmo tempo a hesitação encontra-se representada, torna-se um dos temas da obra; no caso de uma leitura ingênua, o leitor real se identifica com a personagem. Enfim, é importante que o leitor adote uma certa atitude para com o texto: ele recusará tanto a interpretação alegórica quanto a interpretação poética (TODOROV, 2010, p. 39).

Os textos mais representativos deste gênero são obras europeias do século XIX em que entidades obscuras, fantasmas, duplos, forças desconhecidas, espíritos, gênios maus, fazem sua aparição. Usualmente visavam provocar medo. Todorov, no entanto, descarta, muito apropriadamente, um conjunto de temas sobrenaturais ou a possível - mas nunca segura sensação de medo provocada no leitor como sendo os elementos definidores do gênero (TODOROV, 2010, p. 40-41). Sua solução é extremamente simples e convincente, na medida em que consegue, com praticamente um único critério, abarcar ampla gama de narrativas similares.

Se a hesitação - e, portanto, o confronto entre real e irreal, natural e sobrenatural, explicável e inexplicável - marca a narrativa fantástica, no Realismo Mágico ${ }^{7}$ estes elementos díspares não estão em confronto; apresentam-se em perfeita harmonia no enredo. $\mathrm{O}$ irreal, na narrativa, surge como algo natural no texto.

A expressão Realismo Mágico, não custa lembrar, foi primeiramente utilizada por Franz Roh, em 1925, num texto intitulado Magic Realism: Post-Expressionism (FARIS; ZAMORA, 1995, p. 15-31), para, na ocasião, discutir o estilo de pintura que sucedera o pós-expressionismo

\footnotetext{
${ }^{7}$ Há uma discussão sobre o adjetivo: se deveria ser Realismo mágico, maravilhoso ou fantástico. Embora concorde com a análise desenvolvida por Irlemar Chiampi (2008, p. 43-50) no sentido de ser mais precisa a expressão Realismo Maravilhoso, prefiro ainda assim me referir ao Realismo Mágico. Isto por duas razões: primeiro porque neste caso trata-se de uma discussão nominalista: está-se a discutir o melhor nome para um mesmo fenômeno subjacente. Segundo porque, privilegiando o aspecto didático, penso que utilizar "maravilhoso" provocaria talvez mais uma confusão desnecessária no momento de se distinguir as correntes, em particular o Realismo Maravilhoso (como quer a autora) do Maravilhoso.
}

Anu. Lit., Florianópolis, v. 23, n. 2, p. 80-99, 2018. ISSNe 2175-7917 
na Europa. Mas é com o cubano Alejo Carpentier ${ }^{8}$ que se delineia a noção de um real maravilhoso existente e vinculado ao continente americano, bem como associado aos traços naturais, históricos, míticos - de um território que se revelava extraordinário aos olhos do colonizador europeu.

O Realismo Mágico, portanto, além de estar supostamente vinculado à sua origem latino-americana ${ }^{9}$, representaria, na Literatura, certa transposição do maravilhoso encontrado em terras americanas para o estilo literário de boa parte deste continente - do México para baixo, mais precisamente. Sobre estes pontos, discorre Irlemar Chiampi que o Realismo Maravilhoso

não é uma modalidade narrativa exclusiva da literatura hispano-americana", mas reconhece que esta referência cultural de algum modo "se legitima à simples constatação de que, na América Hispânica, a continuidade e a renovação da produção ficcional vem marcada pela busca de significar a identidade do continente americano (CHIAMPI, 2008, p. 95-96) ${ }^{10}$.

Tentando definir este maravilhoso americano e ao mesmo tempo criticando as tentativas de criá-lo a partir da literatura europeia, diz Alejo Carpentier (2014, p. 09) no antológico prólogo de seu romance $O$ reino deste mundo

[...] o maravilhoso começa a sê-lo de maneira inequívoca quando surge de uma alteração da realidade (o milagre), de uma revelação privilegiada da realidade, de uma iluminação inabitual ou especialmente favorecedora das inadvertidas riquezas da realidade, de uma ampliação das escalas e categorias da realidade, percebidas com particular intensidade em virtude de uma exaltação do espírito que o conduz a um modo de 'estado de limite'. Para começar, a sensação do maravilhoso pressupõe uma fé. Os que não acreditam

\footnotetext{
${ }^{8}$ CARPENTIER, Alejo (1949), “On the Marvelous Real in America” In: Faris e Zamora (1995, p. 75-88).

${ }^{9}$ Os teóricos do Realismo Mágico, é necessário sublinhar, quando se referem à Literatura Latino-Americana, estão a tratar, na verdade, da Literatura Hispano-americana. O Brasil, neste como em outros contextos (políticos, culturais, históricos) tende a se excluir - ou a ser excluído - da chamada cultura latino-americana. O tema é complexo e por si só mereceria um estudo próprio. A uma pergunta formulada por brasileira a Cortázar numa de suas aulas em Berkeley, o escritor argentino respondeu: “[...] quero pedir desculpas pelo fato de que falando da América Latina talvez e eventualmente tenha citado o Brasil, mas nunca o citei de maneira direta. Sei muito bem que os brasileiros costumam queixar-se - mas se queixam com tal bondade e tal generosidade que para mim ainda é pior - de que nós, os países latino-americanos de língua espanhola os deixamos demasiado de lado em matérias culturais simplesmente por uma questão de tipo idiomático. Isto é verdade em princípio: acontece que nós, argentinos, uruguaios, colombianos não falamos português e sobretudo não lemos português; isto cria a terrível divisão idiomática que pode separar uma cultura ou uma civilização de outra" (CORTÁZAR, 2015, p. 291).

${ }^{10}$ Esta exclusividade latino-americana vem sendo contestada. Em minha pesquisa ainda incipiente, encontrei títulos que associam o Realismo Mágico a narrativas produzidas por escritores que não são latino-americanos que sequer escrevem em espanhol, diga-se de passagem. Cito, de modo exemplificativo, os seguintes, encontrados tanto na bibliografia que segue abaixo quanto em minhas pesquisas na rede mundial de computadores: Past-On Stories: History and Magically Real, Morrison and Allende on Call; Magical Archetypes: Midlife Miracles in the Satanic Verses; The Magic of Identity: Magic Realism in Modern Japanese Fiction (estes se encontram na obra de FARIS e ZAMORA, 1995); Migrancy and Metamorphosis in Salman Rushdie's The Satanic Verses (WARNES, 2009); O realismo mágico e seus desdobramentos em romances de José Saramago (Ainda não temos a referência deste livro. Encontramo-lo em consulta ao site da Amazon, no link https://www.amazon.es/gp/product/3639747283/ref=ox_sc_sfl_title_2?ie=UTF8\&psc=1\&smid=AB1X0MCLW BCG6. A autora chama-se Tania Mara Antonietti Lopes); Murilo Rubião e o Realismo Mágico (CAMARANI, 2008); José J. Veiga: Os pecados da Tribo - Realismo Maravilhoso à brasileira (MARCÍLIO, 2010); A recepção do Realismo Mágico na Literatura Portuguesa Contemporânea (BRANCO, 2008), entre outros.
}

Anu. Lit., Florianópolis, v. 23, n. 2, p. 80-99, 2018. ISSNe 2175-7917 
em santos não podem curar-se com milagres de santos, nem os que não são Quixotes podem se meter, em corpo, alma e bens, no mundo de Amadís de Gaula ou Tirante, o Branco.

Quanto aos traços discursivos do Realismo Mágico, reproduzo algumas das considerações de Chiampi: 1) a produção de um efeito de encantamento; 2) a enunciação problematizada, engendrando diálogos entre narrador e narratário; 3) a remissão ao "real maravilhoso" de origem americana; 4) a não disjunção entre o "real" e o "maravilhoso"; 5) existência de uma combinatória entre as duas modalidades, promovendo-se a "desnaturalização do real e a naturalização do maravilhoso" (CHIAMPI, 2008, p. 157-158). Sobre a combinatória mencionada, o aspecto sobrenatural surge em meio a uma narrativa até então realista, mas não a distorce; adapta-se a ela de modo natural, sem estremecimento ou ruptura do texto.

Na minha experiência pessoal, enxergo o elemento mágico desta corrente como de teor altamente poético. Quando em Cem anos de Solidão, de Gabriel García Marquez, uma personagem começa a levitar e ascende aos céus, ou espíritos conversam com os mortos; quando em Pedro Páramo, de Juan Rulfo, o leitor imerge num universo ficcional tão intangível que não consegue mais distinguir se as vozes narrativas são de personagens vivos ou de personagens mortos; quando se descobre, em $A$ invenção de Morel, de Adolfo Bioy Casares (2016), a natureza da mulher por quem a personagem se apaixonara, isolado em sua ilha fantástica; em todos estes casos e em muitos outros, há uma força poética inegável subjacente ao texto.

Vem-me à memória, para ilustrar, um capítulo de Cem anos de solidão. Nele a família Buendía é atingida pela "peste da insônia" (MARQUEZ, 2017, p. 51-56). Ninguém logra êxito em adormecer e um dos efeitos da doença é a perda de memória. Os habitantes da casa sonham acordados e naquele estado de "alucinada lucidez não apenas viam as imagens dos seus próprios sonhos, mas uns viam as imagens sonhadas pelos outros". Aureliano Buendía inventa então um método para que não se esquecessem de tudo: começa a grudar papeis nos objetos: "cadeira, relógio, porta, parede, cama caçarola", cada coisa com o seu nome: com seu respectivo nome (imagine-se toda uma casa e, posteriormente, uma aldeia assim). Como as funções de cada coisa também podiam ser esquecidas, penduravam no cachaço da vaca: "Esta é a vaca e deve ser ordenhada todas as manhãs para que produza leite, e o leite deve ser fervido para ser misturado com o café e fazer café com leite".

E assim, conclui o narrador, "continuavam vivendo numa realidade escorregadia, momentaneamente capturada pelas palavras, mas que fugiria sem remédio quando fosse esquecido o valor da letra escrita". Impressionam neste trecho o poder da imaginação, as imagens utilizadas, o caráter onírico, mas também, quanto à forma, a maneira gritantemente poética encontrada pelo autor, a meu ver, de relatar a passagem do tempo. Um autor realista talvez dissesse simplesmente: "Anos depois...".

Em trecho de sua Valise de Cronópio (CORTÁZAR, 2013b, p. 71), Julio Cortázar ilustra bem esta ideia ao afirmar que em nosso tempo 
o romance inclina-se para a realidade imediata, o que está mais aquém de toda descrição e só admite ser apreendido na imagem de raiz poética que a persegue e revela. Alguns romancistas reconhecem que nesse fundo inacessível para suas pinças dialéticas joga-se o jogo do mistério humano, o suporte de suas objetivações posteriores. E então se precipitam pelo caminho poético, arremessam pela amurada a linguagem mediadora, substituem a fórmula pelo ensalmo, a descrição pela visão, a ciência pela magia.

Este é um breve apanhado de quem são os desafiantes do Realismo. Não é possível explorar a complexidade de cada um deles num artigo com limites tão estreitos. Proponho fazêlo em capítulo próprio da tese. O que me interessa é perceber, de modo preliminar, que as narrativas aludidas no tópico um não parecem pertencer a qualquer destes gêneros.

Realistas não são, obviamente. Maravilhosas também não, porque todas ocorrem, em parte substancial, no interior de parâmetros realistas, até a ocorrência de um evento insólito não previsto, previsível ou esperado pelo leitor (como no Maravilhoso se espera) - que de algum modo provoca uma cisão no texto, uma ruptura radical, dividindo-o em um antes e um depois. No Realismo Mágico, inexiste tal ruptura: a narrativa prossegue sem sobressaltos porque os eventos insólitos nela ocorridos são harmônicos em relação ao que se narra e à maneira poética, mágica - como se narra. De Fantástico também não há que se falar porque a quebra da racionalidade ou do aspecto verossímil do texto não é objeto de hesitação alguma, muito pelo contrário: o insólito advém de modo expresso e quase, dir-se-ia, brutal.

Então como se poderia analisar aquele tipo de ficção? Pode-se afirmar, meramente, que são insólitas?

\section{Uma insólita confusão}

Sim, são insólitas. Mas todos os gêneros estudados até aqui o são - salvo o realista, claro. Isto porque o significado de "insólito" é amplo o suficiente para abraçar, em seu campo semântico, tudo o que não seja concretamente real, usual, comum. E é justamente sobre a polissemia da palavra que se gerou, na literatura, inúmeras concepções acerca do insólito, merecendo esta questão, portanto, análise mais apurada.

Trago, para iniciar, duas definições encontradas em grandes dicionários. A primeira no Houaiss (2001, p. 1625):

Adj. (CDPI 236) 1 que não é habitual; infrequente, raro, incomum, anormal [enfermidade i.] 2 que se opõe aos usos e costumes; que é contrário às regras, à tradição [um estilo i.] [comportamento i.] • ETIM lat. Insolitus, a,um 'não acostumado, estranho, alheio' ○ SIN/VAR ver antonímia de comum $\circ$ ANT acostumado, comum, habitual, sólito; ver tb. sinonímia de comum.

No Petit Robert (ROBERT, 1996, p. 1184) dicionário de língua francesa, eis o verbete:

adj. - 1495; lat. insolitus, de solere "avoir coutume de" • Que étonne, surprend par son caractere inaccoutumé, contraire à l'usage, aux habitudes (pej. Jusqu'aux XXe s.; plutôt laudatif, de nos jours). $\Rightarrow$ anormal, bizarre, étonnant, extraordinnaire, inhabituel, rare. Événement insolite. Visite insolite. Mise, 
tênue, apparence, aspect insolite. Personnage insolite $\Rightarrow$ excentrique, extgravagant. "Les terminaisons [de lettres] insolites ne sont à risquer qu'entre des gens d'esprit" (Romains) - SUBST. Recherche de l'insolite et du bizarre, em poésie o CONTR. Accoutumé, familier, normal.

Destaco que há dois grupos de significados que é preciso distinguir. No primeiro, cuja nota peculiar é a raridade, percebe-se que o insólito é não usual, incomum, não costumeiro. Ora, quem diz raro, diz possivel de acontecer, embora em raras ocasiões. No segundo grupo, ao contrário, a nota é de impossibilidade, ou seja, o insólito é o que excede o ordinário, afronta as leis da natureza, é sobrenatural ou anormal. As narrativas que mencionei só podem se enquadrar neste último campo semântico.

Enquanto no Fantástico se hesita quanto à ocorrência de um evento sobrenatural que, no mais das vezes, se encontra plenamente envolvido em mistério; enquanto no Realismo Mágico o caráter de encantamento contribui para acentuar a beleza do texto e para flertar com aspectos mágicos da realidade; nesta categoria que estou a tentar delimitar não há concessão de nenhum gênero: o insólito rompe com o real da maneira mais expressiva (sem hesitações, sem poesia) possível $^{11}$.

O professor Flávio García, na tentativa de definir o evento insólito e numa postura que prima pela abordagem dos significados constantes no dicionário, aduz que:

os eventos insólitos seriam aqueles que não são frequentes de acontecer, são raros, poucos costumeiros, inabituais, inusuais, incomuns, anormais, contrariam o uso, os costumes, as regras e as tradições, enfim, surpreendem ou decepcionam o senso comum, as expectativas cotidianas correspondentes a dada cultura, a dado momento, a dada e específica experenciação da realidade (GARCÍA, 2007, p. 19).

Estas tentativas, embora esclareçam a etimologia do termo, pouco servem para realizar distinções de gênero dentro das diversas categorias de insólito encontradas na fícção. Acrescente-se a isto a diversidade de perspectivas sob as quais se aborda a expressão. Ora é visto (o insólito), como em Oropeza Prada, enquanto "traço, inesperado dentro dos padrões realistas, que se manifestam em quaisquer das categorias da narrativa - personagem ou espaço ou tempo" (SILVA, 2016, p. 19), ou, dito de outro modo, como "aspecto intrínseco às estratégias de construção narrativa" (GARCÍA; BATALHA, 2012, p. 14) presentes na produção do Fantástico, do Maravilhoso, do Estranho, do Realismo Maravilhoso, do Absurdo, do Sobrenatural, entre outros; ora como foco de "desenvolvimento temático com forte ressonância existencial" (Carlos Reis apud GARCÍA; BATALHA 2012, p. 60); ou como, na visão de Maria João Simões (GARCÍA; BATALHA, 2012, p. 71), "uma estratégia conducente ao fantástico". Mais condizente com minha visão, como será adiante explicitado, é a noção do insólito

\footnotetext{
${ }^{11}$ Numa feliz passagem, Myriam Boucharenc bem traduziu esse caráter ao afirmar que "proche de l'étrange par son pouvoir de dépaysement, l'insolite n'est pas très éloigné du fantastique. Comme lui, il provient d'une intrusion dans la vie quotidienne non du surnaturel' mais du plus inassignable 'bizarre'. Voilà qui le distingue du merveilleux des contes que suppose, selon Tzvetan Todorov, um surnaturel accepté" (BOUCHARENC, 2011, p. 13).
} 
na perspectiva do Professor Flávio García quando propõe, no artigo $O$ insólito na construção da narrativa, enxergá-lo como um "macrogênero" - "reunião de vários gêneros que têm em comum, entre si, a categoria do insólito como traço distintivo" (GARCÍA, 2008, p. 07). Desenvolvo em seguida os argumentos para sustentar esta postura, bem como apresento um rearranjo provisório da matéria.

\section{Rearranjo provisório}

Parece-me que a primeira divisão a ser estabelecida, em termos didáticos, é a que contrapõe o Realismo à Fantasia - ou ao Insólito em sentido amplo (ISA). De fato, só consigo enxergar duas formas de perceber a ficção de um modo geral: ou ela pretende se manter fiel à realidade que nós conhecemos, respeitando as leis da natureza, tal qual se apresenta no estado atual do nosso conhecimento; ou ela, simplesmente, desvia-se desta pretensão. Quando se desvia, produz narrativas que, em diferentes graus (Fantástico, Realismo Mágico, Maravilhoso), desafiam nossa percepção do real, provocam ambiguidade ou simplesmente rompem o compromisso com a lógica, a natureza e a ciência.

Portanto, ao Realismo enquanto macrogênero ${ }^{12}$, opõe-se o Insólito em Sentido Amplo - também como macrogênero. É claro, poder-se-ia, por um lado, ao invés de chamar esta grande categoria de ISA, chamá-la de Fantástico. É o que fazem - de modo bem gratuito, a meu ver muitos autores. Tanto teóricos da Literatura quanto escritores. Entre eles podemos citar nomes da envergadura de Jorge Luís Borges ou Julio Cortázar. Ana Lúcia Trevisan (2014, p. 13), ao falar da "literatura fantástica", por exemplo, nela inclui Julio Cortázar, Juan Rufo, Jorge Luís Borges, Carlos Fuentes, Bioy Casares e Gabriel García Marquez.

Há dois problemas neste tipo de afirmação. Primeiro (e este é recorrente), diz-se "fantástico" como se fosse gênero ${ }^{13}$, e dentro do fantástico se coloca tudo o que há de insólito, ainda que a maioria dos autores constantes da lista acima, em particular, sejam considerados filiados ao Realismo Mágico. Segundo, a rigor não se pode afirmar que um autor é "fantástico" ou "insólito", mas que tal ou qual texto seu é - ou não é. Isto porque nem tudo o que produzem se vincula a uma única e exclusiva corrente. Veja-se o exemplo de Cortázar, que publica um livro como Bestiário (coletânea de contos onde há de tudo: fantástico, insólito, etc), mas também uma obra como o romance que o lançou ao estrelato $O$ jogo da amarelinha ou, ainda, a coletânea de contos As armas secretas, dois livros predominantemente realistas.

Seja como for, não se deve, quando a pretensão é construir um discurso coerente e uniforme, capaz de gerar diálogos produtivos, falar de Fantástico (ou de qualquer outro gênero, diga-se de passagem) sem levar em consideração o chamado estado da arte. E o estado da arte, nesse caso, passa necessariamente por Tzvetan Todorov. Quando se opta por usar o termo

\footnotetext{
12 É evidente que o Realismo também se subdivide em subgêneros: romances policiais, obras cômicas, romances históricos, entre tantos outros. O que Todorov denominou de Estranho também tem natureza realista, na medida em que todo caráter insólito da narrativa, ao final, é explicado racionalmente. Superficialmente parece desafiar a realidade, mas no fundo ancora-se no real, o que o leitor só descobre no fim do texto.

${ }^{13}$ Esta parece ser uma postura predominantemente latino-americana.
} 
"fantástico" deste modo não técnico, com tamanha amplitude conceitual ${ }^{14}$, provoca-se a confusão que hoje encontramos na literatura sobre o tema.

Poderia, por outro lado, como fazem alguns, adotar a expressão - para um conjunto variado, mas não bem definido, de narrativas que contém o insólito - de "novos discursos do fantástico" (SILVA, 2016) ou "novo fantástico" (TODOROV, 2010, p. 182), mas esta postura é passível da mesma crítica feita acima, bem como daquela que usualmente se faz à nomenclatura "pós-modernidade". Aponta para uma ausência de qualificação precisa dos fenômenos, preferindo-se, a partir de um critério cronológico, definir um contexto como posterior ao seu antecedente. Estas expressões nada me dizem sobre seu conteúdo, além de não se mostrarem aptas a distinguir o tipo específico de narrativa de que me ocupo aqui.

Um teórico - e nesse sentido os escritores que não são teóricos são menos culpados destes deslizes - deve expressar seu entendimento levando em consideração o que foi dito anteriormente sobre o sujeito que está a tratar, de modo que deveria esclarecer em que sentido está utilizando a expressão "fantástico". Por não o fazer é que se torna quase impraticável compreender muitos dos discursos que empregam tais categorias. Se, como disse no início, não há tanta confusão no que se refere ao Maravilhoso e ao Realismo Mágico, o mesmo não pode ser dito quanto ao Fantástico e ao Insólito.

O que chamo de Insólito em Sentido Amplo é o gênero que se apresenta como oposição - leve, moderada ou violenta - aos pressupostos do Realismo e que se reparte em subgêneros, tais como o Fantástico, o Realismo Mágico, o Maravilhoso e outros. Não me arrisco a enumerálos todos: seria temerário. É facilmente perceptível - e o afirmo a partir de minhas leituras que há zonas cinzentas em meio a este corpus insólito, narrativas cujo enquadramento não se revela tarefa das mais tranquilas. É óbvio, também, que se o insólito é gênero que compreende os subgêneros citados, há eventos insólitos em todos eles.

Em outras palavras, tudo que é fantástico (ou maravilhoso, ou real mágico) é insólito, mas nem tudo que é insólito é fantástico (ou maravilhoso, etc.).

De outra feita, não enxergo a necessidade de tudo classificar. Não se trata aqui de uma compulsão por "dar nomes aos bois", como diz o ditado. O que me parece relevante é estudar aquelas categorias que, por sua repetição no tempo, pelo conjunto de características em comum $^{15}$, pela sua lógica interna e proliferação, mereçam ser reconhecidas como entidades distintas, dignas de análise por talvez representarem algo mais do que um simples modismo ou a produção peculiar de um único artista. Este parece ser o caso das narrativas que apresentei no primeiro tópico.

\footnotetext{
${ }^{14}$ Não creio salutar, por exemplo, adotar a proposta do Professor Carlos Reis (GARCÍA; BATALHA, 2012, p. 60) de falar num "fantástico lato sensu", para evitar maiores confusões num terreno já tão minado pela disparidade conceitual. É o que parece fazer, nesta mesma obra, a professora Maria João Simões, ao intitular seu artigo Fantásticos diferentes: mistério, insólito e estranho em Sá Carneiro e Ana Teresa Pereira (GARCÍA; BATALHA, 2012, p. 70), e o professor Alexander Meireles da Silva, ao mencionar, no início do seu texto intitulado Relações entre espaço e alteridade no Realismo Maravilhoso e na ficção científica, estes subgêneros como sendo "vertentes do fantástico" (fl. 196).

${ }^{15}$ Como diria Todorov a respeito da noção de gênero: "uma regra que funcione para muitos textos", em suma (TODOROV, 2010, p. 08).
} 
Deste modo, considerando haver certo consenso sobre as principais características do Realismo Mágico e do Maravilhoso e, ao mesmo tempo, adotando o conceito restrito de Todorov - com ressalvas que deixo para a tese - acerca do Fantástico, pergunta-se: a que categoria do insólito pertencem os contos mencionados? Merecem tais narrativas um estudo à parte? Gozam de tanta distinção que sua produção seja a ilustração de algum fenômeno do mundo real? E mais: são tão diferentes assim daqueles outros textos insólitos, cujo lugar já se encontra garantido na produção teórica?

\section{O subgênero absurdo ${ }^{16}$ (ou o insólito em sentido estrito)}

Tzvetan Todorov (2010, p. 80), referindo-se expressamente à narrativa $O$ Nariz, de Nikolai Gógol, ao tempo em que rejeita sua natureza fantástica ou alegórica, chama-a de “encarnação pura do absurdo, do impossível". Acrescenta o autor, tentando desvendar-lhe a natureza: "mesmo se aceitássemos as metamorfoses, não se poderia explicar a ausência de reação das personagens que as testemunham. O que Gógol afirma é precisamente o contrassenso".

Ao final de sua obra, ainda afirma que $A$ metamorfose, de Franz Kafka, em que a história já se inicia com a transformação de Gregório Samsa num imenso inseto, fato que pouco parece impressionar seus familiares e próximos, tem a mesma natureza do conto do autor russo: "a coisa mais surpreendente é precisamente a ausência de surpresa diante deste acontecimento inaudito, exatamente como em O nariz de Gógol ("nunca nos espantaremos o suficiente com esta falta de espanto', dizia Camus a propósito de Kafka)” (TODOROV, 2010, p. 177).

Teresa Galarza Ballester (s/a, p. 45), ao fazer a mesma aproximação entre os dois textos, foi muito precisa na descrição de sua natureza:

El mayor Kovaliov pierde su nariz, Gregor Samsa se convierte en escarabajo, y no hay respuesta racional a estos acontecimientos. No obstante, ambos personajes forman parte de um entorno real, de un tiempo concreto, y repentinamente se encuentran ante lo inexplicable, ante el inevitable aprendezaje del sinsentido que aumenta gradualmente su intensidad tras cada contratiempo. El mundo de Gogol e Kafka aparece fijado a uma realidad tan detalladamente distorcionada que nada de la realidad puede acarrear sorpresas.

Ao chamá-las de absurdas, não parecia que Todorov tivesse qualquer intenção de tratálas como um gênero à parte (um gênero absurdo), mas tão somente de expressar seu espanto quanto às suas feições, bem como diferenciá-las muito categoricamente do gênero estudado ao longo de sua clássica obra. Esta interpretação ganha consistência pelo fato de Todorov citar tão somente duas narrativas desta natureza, como a reconhecer que a sua produção representava,

\footnotetext{
${ }^{16}$ Importa deixar claro que não se trata da literatura absurda, nos moldes das obras da filosofia existencialista. Nestas, o absurdo é um sentimento que decorre, entre outros fatores, da constatação de nossa extrema liberdade e da sensação de que não sabemos o que fazer com ela (o famoso "condenados a ser livres" de Jean-Paul Sartre). De qualquer forma, para que esta referência não se torne um fator de confusão é que deveríamos apelidar este subgênero de insólito em sentido estrito (ISE), insólito "puro" ou simplesmente insólito. Em outras palavras, o insólito tout court.
}

Anu. Lit., Florianópolis, v. 23, n. 2, p. 80-99, 2018. ISSNe 2175-7917 
talvez, simplesmente uma peculiaridade, uma escrita própria de dois autores específicos.

O cenário parece ter se alterado. Embora só tenha listado cinco narrativas no início deste trabalho, há inúmeras outras que possuem, por assim dizer, uma estrutura absurda, e que pretendo colacionar como corpus de minha tese. A reprodução, portanto, de ficções cujos conteúdo e forma se assemelham permite enxergar, talvez, um fenômeno distinto daqueles ilustrados pela ficção fantástica, realista-mágica ou maravilhosa.

Passo, tão somente a fim de apontar o direcionamento dos meus estudos, a elencar algumas características deste candidato a subgênero. Esta análise volta-se para a forma, para o que usualmente parece se repetir nestas narrativas, e para os temas subjacentes que o subgênero suscita. Este último ponto evidencia, numa primeira reflexão, uma crise profunda dos pressupostos racionalistas da modernidade, que veio sendo ilustrada ao longo do tempo por subgêneros mais, digamos, amenos.

Em primeiro lugar, não há absurdo sem a ocorrência de determinado evento insólito. Este evento, no entanto, difere em essência dos eventos encontrados nos demais subgêneros. Isto porque ele não provoca ambiguidade (Fantástico) ou encantamento (realismo Mágico). Também não se trata de evento do subgênero Maravilhoso porque não se dá no universo de um reino encantado, mas em meio a um claro contexto realista. O que ele provoca é uma grande interrogação quanto ao seu significado.

Não se trata de um evento que dá ares poéticos à narrativa, integrando-a, mas, ao contrário, rompe com a integridade da narrativa. A partir dele, tudo se torna estranho e questionável. Como se deve, a partir deste evento, encarar o texto? Segundo Jacques Goimard, o insólito é uma "radicalização do fantástico" (BOUCHERANC, 2011, p. 14). Para mim, ele leva o caráter absurdo ao seu ponto máximo de tensão, é o insólito radicalizado. De todos os subgêneros do ISA, é o mais extremista em sua ruptura com o real.

Por esta razão, o insólito em sentido estrito (ISE) ou absurdo ${ }^{17}$ não pode ser, como se vê em alguns sinônimos elencados no dicionário ou por especialistas, raro, inabitual (ou seja, pode acontecer, ainda que raramente) - o evento neste subgênero é simplesmente impossível. Não são, portanto, as ações nele relatadas “possíveis e aceitáveis para o leitor" (GARCÍA apud SILVA, 2016, p. 29). E por serem (claramente, absurdamente) inaceitáveis é que instigam o leitor a se debruçar sobre elas, a questionar o (s) sentido (s) destas narrativas.

Em segundo lugar, além do evento insólito, alguns traços do absurdo parecem ocorrer com frequência. Cito alguns en passant, porque serão desenvolvidos ao longo da tese: 1) a indiferença quase caricatural dos personagens quanto ao acontecimento insólito; 2) a sensação de incomunicabilidade do narrador e do personagem; 3) a presença do personagem enquanto função, sem o desenvolvimento ou aprofundamento de sua personalidade ${ }^{18} \mathrm{e}$, portanto, sua

\footnotetext{
${ }^{17}$ Uma alternativa possível, mas que a meu ver peca pela utilização de um termo que gostaria ficasse restrito à construção todoroviana, é a denominação "neofantástico", de Alazraki. Segundo este autor, "lo neofantástico parte del hecho insólito que se va volvendo aceptable" Roxane Guadalupe Herrera Alvarez apud (GARCÍA; BATALHA, 2012, p. 115).

${ }^{18}$ Duas grandes referências neste sentido são Franz Kafka e José Saramago. Nos dois autores o que mais se vê são "o juiz", "o primeiro ministro", "o ajudante", "o jornalista", etc.
} 
despersonalização; 4) a presença de forças imperiosas às quais o personagem é submetido, sem que o sentido desta imposição lhe seja revelado ${ }^{19}$, sofrendo, nas palavras da professora Cristina Robalo $^{20}$, "um destino imposto pela natureza" (CORDEIRO, 2001, p. 88) a sensação de isolamento e solidão do personagem; 6) a ausência de qualquer atmosfera de mistério, enfim, a lista é meramente exemplificativa.

Este conjunto de fatores, ainda sujeito a ampliação, parecem denotar não só a especificidade de uma categoria como ilustrar uma transformação ocorrida fora do texto. De fato, este tipo de literatura incita questionamentos filosóficos sobre a (s) época (s) em que é produzida, e sua banalização ${ }^{21}$ numa sociedade que se tornou extremamente racional e científica representa no mínimo um paradoxo cujo mistério me interessa investigar. Esta investigação, como é evidente, não pode ser realizada aqui.

Enfim, talvez tenha chegado a hora de revelar os autores das narrativas do primeiro tópico. O nariz (narrativa quatro), como já deixei escapar, é um conto de Nikolai Gógol, constante da coletânea $O$ capote e outras histórias (2011); a primeira narrativa, Blumfeld, um solteirão de meia idade, é da autoria de um gênio do absurdo, Franz Kafka, e encontra-se no livro Narrativas do espólio (2016); a segunda intitula-se $O$ tombo da lua, do português ${ }^{22}$ Mario de Carvalho, e está na obra Casos dos becos das sardinheiras (2015); a terceira é do brasileiro Murilo Rubião, chama-se Teleco, o coelhinho, e faz parte de sua Obra completa (2010); por fim, a última, chamada Carta a uma senhorita em Paris, pertence a um dos mestres do insólito, o argentino Julio Cortázar - está na coletânea (insólita em todos os sentidos possíveis) Bestiário (2013a).

\section{Conclusão}

Mencionei no início do segundo tópico que o Realismo podia ser analisado sob o ponto de vista estático (seu posicionamento face às outras correntes) ou dinâmico/evolutivo (seu surgimento no tempo). Sob esta última perspectiva, é interessante perceber que o Realismo

\footnotetext{
${ }^{19}$ A inevitabilidade de se vomitar coelhos ou de se metamorfosear sem controle; a perda inexplicável de um nariz; a lua que é engolida "sem querer", como resultado de um bocejo; o aparecimento de bolas azuis que saltitam dentro de um quarto, etc.

${ }^{20}$ Muitas das considerações formuladas, bem como das expressões utilizadas pela professora no seu estudo sobre a novela parecem servir perfeitamente para descrever o absurdo tal como estou tentando fazê-lo. Além da questão do destino, a existência de personagens que "vivem a incomunicabilidade e profunda solidão dos seres" (p. 88); a ideia de "indeterminação do herói" (p. 75-77); a presença de uma "estética da ruptura" (p. 152); a descoberta da "arbitrariedade como princípio ordenador do mundo" (p. 177); a execução de uma "estética do desconcerto" (p. 192).

${ }^{21}$ Estou utilizando "banalização" num sentido comum, e não no sentido daqueles que defendem a existência de um "insólito banalizado". Não enxergo um gênero nesta última expressão, mas tão somente uma ocorrência literária, isto é, uma consequência da utilização muitas vezes gratuita do insólito. Discutirei o tema em outra ocasião.

${ }^{22}$ Por falar em autor português, não podemos esquecer de José Saramago. A maioria de suas obras enquadram-se no macrogênero do insólito. A pergunta, que ainda não me vejo com capacidade para responder, é: em qual subgênero? Fantásticas ou maravilhosas não são. Resta saber se se alinham mais ao Realismo Mágico (e há autores defendendo esta tese, inclusive - mas não somente, claro - por referências de Saramago a autores desta corrente, como sua epígrafe lembrando Alejo Carpentier no romance A jangada de pedra) ou ao Absurdo, tal como o estamos delimitando aqui.
}

Anu. Lit., Florianópolis, v. 23, n. 2, p. 80-99, 2018. ISSNe 2175-7917 
representa um breve momento de inflexão na história da narrativa em sentido amplo. Com isto quero dizer que quando homens primitivos narravam suas histórias, ainda antes da escrita, estas eram sobretudo de natureza mítica e, portanto, maravilhosa. Os contos populares, os contos de fadas, nesse mesmo sentido, precedem a empreitada realista. Antes dela, a imaginação exercia seu domínio sem amarras, ou com poucas amarras, com a realidade.

Talvez por isto alguns consideram Dom Quixote, de Miguel de Cervantes, como o pai do romance moderno. Temos nesta história justamente um personagem que vive no universo dos mitos de cavalaria, mas ao seu redor atacam-no de todos os lados os defensores do real, que se riem dele, que se riem da sua imaginação e que o tomam por um louco. De fato, o Cavaleiro da Triste Figura só pode ser considerado lunático numa sociedade que estabeleceu com muita precisão os limites da normalidade. Dom Quixote é, por assim dizer, o último defensor do maravilhoso, antes que o Realismo venha imperar, soberano, por algum tempo.

É tentador enxergar um movimento histórico-dialético nas diversas posturas da Literatura frente à realidade. $\mathrm{O}$ Maravilhoso como tese; o Realismo como antítese; as diversas formas de manifestação do Insólito como síntese (e nova tese). O pensamento parece executar este movimento pendular entre a aceitação de um real consensual e a necessidade de mergulhar no irracional, no obscuro, no inexplicável. O Absurdo, nesse sentido, pode ser considerado como uma reação artística a todas as pretensões sérias de captação do real, ou de explicação do real. É gênero pós-moderno por excelência, sendo seu ídolo nietzschiano a própria concepção de concretude da realidade. Seu "martelo" é a narrativa inexplicável.

A razão de ser, as motivações inerentes à construção deste tipo de Literatura, sua posição no tempo, todas estas questões me parecem constituir um excelente terreno de reflexão. $\mathrm{O}$ Absurdo, é bom que se diga, não representa uma ruptura imprevisível, não ocorreu tal qual nascimento espontâneo, ao contrário: ele vem sendo gestado no seio da Literatura Insólita, tem afinidades com o fantástico e com o realismo mágico. Seu traço distintivo, no entanto, é o grau de divórcio com o real. Ele vai além, transpõe os limites envoltos em mistério ou magia dos gêneros irmãos. Esta transição parece ter ocorrido em algum lugar entre o século XIX e o início do século XX.

Lembre-se, para finalizar esta pequena problematização do insólito, que no conto $O$ nariz, de Gógol, o narrador assim se expressa, quase pedindo desculpas por ousar escrever algo tão estranho quanto uma narrativa onde um nariz abandona seu dono e ganha vida própria:

Eis a história que aconteceu na capital do norte do nosso Estado! Hoje, pela simples percepção de seu conjunto vemos que nela há muito de inverossímil. Já sem falar que é realmente estranha a separação sobrenatural do nariz e sua aparição em diferentes lugares sob o disfarce de conselheiro de Estado - como Kovaliov não percebeu que não podia anunciar na imprensa o desaparecimento de um nariz? Não estou falando no sentido de achar cara a publicação do anúncio: isso seria absurdo e nada tenho a ver com gente ambiciosa. Mas isso é indecente, esquisito, ruim! E depois - como o nariz achou de aparecer no pão assado e com o próprio Ivan Yákovlievitch?... não, isso de maneira nenhuma eu consigo entender, decididamente não entendo! Porém o que é mais estranho, o que é mais incompreensível é como os autores 
podem escolher semelhantes temas. Confesso que isso é simplesmente inconcebível, é de fato... não, não, absolutamente não entendo. Em primeiro lugar, isso não traz decididamente nenhum proveito à pátria; em segundo... em segundo lugar também não há nenhum proveito. Simplesmente não entendo o que isso...

Entretanto, apesar de tudo, embora, é claro, se possa admitir isso, aquilo e aquilo outro, pode-se até... ora bolas, onde é que não acontecem absurdos? E mesmo assim é só pensar um pouco para ver que, palavra, em tudo isso há alguma coisa. Digam o que disserem, mas histórias semelhantes acontecem pelo mundo; raramente, mas acontecem (GÓGOL, 2011, p. 103-104).

É interessante ver a tentativa do narrador de comicamente explicar o absurdo num século onde imperava o Realismo. Mais significativo ainda é constatar que quando Kafka começa sua criação literária insólita, nenhum dos seus personagens ou narradores pedirá desculpas por o que quer que seja. O Absurdo marca seu terreno, aparentemente nada lhe ficará atravessado na garganta - nem mesmo um coelhinho.

\section{Referências}

BALLESTER, Teresa Galarza (s/a). Gogol y Kafka: la risa, la ironia y el absurdo, El cuento em Red. Revista Electrónica de Estudios sobre la Ficción Breve. Disponível em: $<$ http://bidi.xoc.uam.mx/MostrarPDF.php> Acesso em: 23/12/2017.

BOUCHARENC, Myriam. De l'insolite. Essai sur la littérature du XXe siècle. Paris: Hermann Éditeurs, 2011.

BRANCO, Isabel Rute Araújo. A recepção do realismo mágico na literatura portuguesa contemporânea. Dissertação de mestrado em Estudos Portugueses. Universidade Nova de Lisboa, 2008.

BRETON, André. Manifestes du surréalisme. Saint-Amand: Galimard, 2005.

CARPENTIER, Alejo. O reino deste mundo. São Paulo: Martins Fontes, 2014.

CARVALHO, Mário de. Casos do beco das Sardinheiras. Porto: Porto Editora, 2015.

CASARES, Alfredo Bioy. A invenção de Morel. São Paulo: Biblioteca Azul, 2016.

CHIAMPI, Irlemar. O realismo maravilhoso. São Paulo: Perspectiva, 2008.

CORDEIRO, Cristina Robalo. Lógica do incerto. Introdução à teoria da novela. Coimbra: Minerva, 2001.

CORTÁZAR, Julio. Histórias de cronópios e famas. Rio de Janeiro: Edições Best Bolso, 2017. . Aulas de literatura. Rio de Janeiro: Civilização Brasileira, 2015. . Bestiário. Rio de Janeiro: Editora Civilização Brasileira, 2013a. . Valise de Cronópio. São Paulo: Perspectiva, 2013b. 
. Octaedro. Rio de Janeiro: Edições Best Bolso, 2013c.

ECO, Umberto. Seis passeios pelos bosques da ficção. São Paulo : Companhia das Letras, 2017.

FARIS, Wendy B; ZAMORA, Lois Parkinson (Eds.). Magical Realism. Theory, History, Community. San Bernardino: Duke University Press, 1995.

GARCÍA, Flavio; BATALHA, Maria Cristina (Org). Vertentes teóricas e ficcionais do Insólito. Rio de Janeiro: Caetés, 2012.

GÓGOL, Nikolai. O capote e outras histórias. São Paulo: Editora 34, 2011.

HOUAISS, Antônio. Dicionário Houaiss de Língua Portuguesa. Rio de Janeiro: Editora Objetiva, 2001.

KAFKA, Franz. Narrativas do espólio. São Paulo: Companhia das Letras, 2016.

MARCÍlLIO, Josué (2010), Os pecados da Tribo - Realismo Maravilhoso à brasileira. Disponível em: <http://livros01.livrosgratis.com.br/ea000896.pdf> Acesso em: 21/06/2018.

MARQUEZ, Gabriel García. Cem anos de solidão. Rio de Janeiro: Editora Record, 2017.

ROBERT, Paul (1996), Le Nouveau Petit Robert. Paris: Dictionnaires Le Robert.

RUBIÃO, Murilo. Obra completa. São Paulo: Companhia das Letras, 2010.

SARAMAGO, José. Jangada de pedra. Porto: Porto Editora, 2015.

SILVA, Luciana Morais da. Figurações da personagem e o universo insólito dos novos discursos do fantástico: narrativas curtas de Murilo Rubião, Mário de Carvalho e Mia Couto. Tese de Doutoramento em Literatura de Língua Portuguesa. Universidade de Coimbra, 2016. Disponível em: <http://hdl.handle.net/10316/39121> Acesso em: 12/10/2017.

TODOROV, Tzvetan. Introdução à literatura fantástica. São Paulo: Perspectiva, 2010.

TOLKIEN, J. R. R. Árvore e Folha. São Paulo: Martins Fontes, 2017.

TREVISAN, Ana Lúcia. Imagens do insólito e do maravilhoso: construções da historicidade na literatura hispano-americana. A cor das letras - UEFS, 15, p. 11-26, 2014. Disponível em: http://periodicos.uefs.br/index.php/acordasletras/article/view/1427. Acesso em 14/10/2018.

WARNES, Christopher. Magical Realism and the Postcolonial Novel. New York: Palgrave Macmillan, 2009.

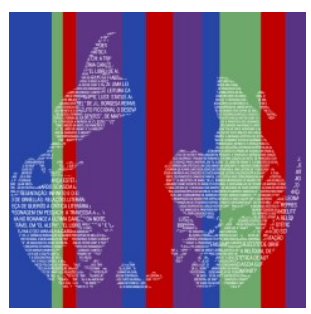

